\title{
Morphology, ultrastructure and molecular phylogeny of Johsia chumphonensis gen. et sp. nov. and Parvodinium parvulum comb. nov. (Peridiniopsidaceae, Dinophyceae)
}

\author{
Luo Zhaohe ${ }^{1}$, Mertens Kenneth ${ }^{2}$, Gu Haifeng ${ }^{1,3,}{ }^{*}$, Wang Na ${ }^{1}$, Wu Yiran ${ }^{1}$, Uttayarnmanee Praderm ${ }^{4}$,
} Pransilpa Mitila ${ }^{5}$, Roeroe Kakaskasen Andreas ${ }^{6}$

\begin{abstract}
1 Third Institute of Oceanography, Ministry of Natural Resources, Xiamen 361005, China
2 Ifremer, LER BO, Station de Biologie Marine, Place de la Croix, BP40537, F-29185 Concarneau

CEDEX, France

${ }^{3}$ School of Marine Sciences, Nanjing University of Information Science and Technology , Nanjing

210044, China

${ }^{4}$ Marine and Coastal Resources Research and Development Center , Central Gulf of Thailand,

Department of Marine and Coastal Resources, Chumphon, 86000, Thailand

${ }^{5}$ Marine and Coastal Resources Research and Development Center , Eastern Gulf of Thailand,

Department of Marine and Coastal Resources, Rayong, 21170, Thailand

${ }^{6}$ Sam Ratulangi University, Sulawesi Utara, Manado, 95115, Indonesia

* Corresponding author : Haifeng Gu, email address : guhaifeng@tio.org.cn
\end{abstract}

\begin{abstract}
:
The family Peridiniopsidaceae encompasses mainly freshwater species of the genera Peridiniopsis, Palatinus and Parvodinium. Only one benthic, marine species 'Scrippsiella' hexapraecingula has been attributed to this family. Here we established five strains by isolating single Parvodinium-like cells from the marine Gulf of Thailand, Hainan Island waters (China), off Manado (Indonesia) and from a freshwater reservoir in Fuzhou (China). All strains were examined with light, scanning and transmission electron microscopy, and their SSU, ITS-5.8S and partial LSU rRNA regions were sequenced. Four marine strains share a plate formula of $\mathrm{Po}, \mathrm{cp}, \mathrm{X}, 4^{\prime}, 2 \mathrm{a}, 6$ 6", $^{\prime} \mathrm{C}, 4 \mathrm{~S}, 5^{\prime \prime \prime}, 2^{\prime \prime \prime \prime}$ and are herein attributed to a new genus Johsia as J. chumphonensis gen. et sp. nov. Its theca is characterized by an epitheca 1.5 times as long as the hypotheca in dorsal view and a 2 a plate about half the size of $1 \mathrm{a}$. A type B eyespot was observed in J. chumphonensis comprising two rows of lipid globules within a chloroplast with a single row of crystals overlying the eyespot. Production of spherical cysts was observed in culture. The freshwater strain shows a plate pattern of Po, cp, X, 4', 2a, 7", 6C, 5S, 5"', 2"'", characterized by two unequal antapical plates and a lack of antapical spines, fitting the description of Peridinium parvulum, which was transferred to Parvodinium as P. parvulum comb. nov. In this species, a type A eyespot was observed comprising four rows of lipid globules within a chloroplast. A molecular phylogeny was inferred based on concatenated data from SSU, ITS-5.8S and partial LSU rRNA gene sequences using maximum likelihood and Bayesian inference. Our results show that Johsia is nested within the Peridiniopsidaceae and is a sister clade to Peridiniopsis borgei and the strain UTEX1948 identified as 'Scrippsiella' hexapraecingula with three anterior intercalary plates.
\end{abstract}


Keywords : Cyst, dinoflagellate, eyespot, freshwater, immotile cell, Peridinium parvulum 


\section{Introduction}

The order Peridiniales includes thecate dinoflagellates with a symmetrical first apical plate and two more or less symmetrical antapical plates (Fensome et al., 1993). The majority of peridinialean species can be reliably placed into one of the families belonging to the Peridiniales, including Heterocapsaceae, Kryptoperidiniaceae, and Peridiniaceae, however, the systematic position on family level of some species/genera is still uncertain, such as Bysmatrum M.A.Faust \& Steidinger, and Vulcanodinium Nézan \& Chomérat (Anglès et al., 2017; Čalasan et al., 2019; Luo et al., 2019). Many freshwater peridinialean species belong to the family Peridiniaceae (Moestrup \& Calado, 2018). Several genera have now been transferred out of this family: recently, the new family Peridiniopsidaceae was erected to encompass Peridiniopsis Lemmermann, Palatinus Craveiro, Calado, Daugbjerg \& Moestrup, and Parvodinium Carty with Peridiniopsis as type genus (Gottschling et al., 2017). All these genera have at most two anterior intercalary plates and six cingular plates and thus can be separated from Peridinium Ehrenberg (the type of family Peridiniaceae) in that the latter has five cingular plates and three anterior intercalary plates (Bourrelly, 1968).

Besides the differences in plate pattern, the presence/absence of a microtubular strand of the peduncle (MSP) was used to differentiate Peridiniopsidaceae from Peridiniaceae (Gottschling et al., 2017). A reduced MSP is present in Palatinus and Peridiniopsis but absent in Peridinium cinctum (O.F.Müller) Ehrenberg (Spector \& Triemer, 1979; Calado \& Moestrup 2002; Craveiro et al., 2009). Both families share a 
type A eyespot comprising several rows of lipid globules within the chloroplast (Moestrup \& Daugbjerg, 2007), as reported in Peridinium and Palatinus (Calado et al., 1999; Craveiro et al., 2009), while a type B eyespot was reported only for Peridiniopsidaceae (Peridiniopsis borgei; Calado \& Moestrup, 2002). Radial chloroplasts without a pyrenoid were reported in Peridinium cinctum (Spector \& Triemer, 1979). In contrast, Peridiniopsis and Palatinus possess radial chloroplasts with a central pyrenoid (Calado \& Moestrup, 2002; Craveiro et al., 2009). However, the chloroplast can only be considered as a useful character to differentiate dinoflagellates at species level (Schnepf \& Elbrächter, 1999).

Among 2294 extant dinoflagellate species (Gómez, 2012), only 350 species inhabit freshwater (Mertens et al., 2012; Moestrup \& Calado, 2018). Marine-tofreshwater transitions are now considered frequent in dinoflagellates, including ten transitions in Peridiniales (Čalasan et al., 2019). Some families, such as Thoracosphaeraceae encompass both marine and freshwater genera (Craveiro et al., 2016). Even within the same genus both marine and freshwater species can be found, as exemplified by Biecheleria Moestrup, K.Lindberg \& Daugbjerg (Raho et al., 2018), which is also observed on species level for the species Huia caspica (Ostenfeld) H.Gu, K.N.Mertens \& T.T.Liu, which is known to be present in both marine and freshwater environments (Gu et al., 2016). Peridiniopsidaceae includes mostly freshwater species, but one benthic species identified as "Scrippsiella" hexapraecingula T.Horiguchi \& Chihara from tidal pools appears to be closely related to Peridiniopsis borgei Lemmermann (Kretschmann et al., 2018a); whether other 
marine species belong to this clade is not yet known.

Parvodinium species are often small and currently include 12 accepted species (Carty, 2008; Kretschmann et al., 2018b; Kretschmann et al., 2019). All of them are exclusively freshwater and most species have two anterior intercalary plates. Three distinct conformations of the two intercalary plates were reported for Parvodinium, even in clonal strains (Elbrächter \& Meyer, 2001; Kretschmann et al., 2018b), including a conjunctum tabulation (the third apical plate shares one plate suture with the fourth precingular plate leading to the separation of the two intercalary plates), a remotum tabulation (Plates $3^{\prime}$ and $4^{\prime \prime}$ are separated by the two intercalary plates which contact broadly), and a contactum tabulation (Plates $3^{\prime}$ and $4^{\prime \prime}$ as well as the two intercalary plates all contact in a single point). A presumed eyespot was reported in species of Parvodinium (Kretschmann et al., 2018b), but detailed examination on the ultrastructure has not been carried out. To date, there is only one publication on a Chinese Parvodinium species, namely on Parvodinium umbonatum (F.Stein) Carty (Liu et al., 2008), which suggests that Parvodinium is understudied in China.

In the present study, five strains of Parvodinium-like species were established through single-cell isolation from the marine Gulf of Thailand, from Hainan Island waters (China), off Manado (Indonesia) and from a freshwater reservoir in Fuzhou (China). The five cultured strains were examined morphologically and ultrastructurally, with an emphasis on the eyespot. In addition, small subunit ribosomal RNA (SSU rRNA), partial large subunit ribosomal RNA (LSU rRNA) and internal transcribed spacer region including the 5.8S ribosomal RNA (ITS-5.8S 
rRNA) sequences were determined for the cultured strains and molecular phylogeny was inferred using concatenated SSU, ITS-5.8S and LSU rRNA sequences.

\section{Material and methods}

\section{Sample collection and treatment}

Sandy sediment samples were collected from the seabed by scuba divers off Hainan Island, China, Chumphon, capital of Chumphon Province, Gulf of Thailand, and off Manado (Indonesia) from 2017 to 2019 (Table S1) and placed into polycarbonate bottles containing filtered seawater from the same location. The samples were stirred vigorously to detach the epibenthic cells and the suspension settled in a polycarbonate bottle. The settled material was rinsed with filtered seawater and transferred into a petri dish. Single Parvodinium-like cells were isolated with a micropipette using an inverted Eclipse TS100 (Nikon, Tokyo, Japan) microscope to establish the strains TIO606, TIO890 and TIO966 (Table S1). Plankton samples were collected near a freshwater reservoir near Fuzhou (China) and around Mak Island (inner Gulf of Thailand), using a plankton net, $10 \mu \mathrm{m}$ mesh size, on August 30 and November 17, 2017, respectively. Single cells were isolated with a micropipette using the abovementioned microscope to establish the strains TIO896 and TIO879 (Table S1). Strains were maintained with f/2-Si medium (Guillard \& Ryther, 1962) at $25^{\circ} \mathrm{C}, 90 \mu \mathrm{mol}$ photons $\mathrm{m}^{-2} \mathrm{~s}^{-1}$ under a 12:12 $\mathrm{h}$ light: dark cycle. The medium for marine species was prepared using seawater with a salinity of 30 . 


\section{Light and scanning electron microscopy}

Live cells were examined and photographed using a Zeiss Axio Imager light microscope (Carl Zeiss, Göttingen, Germany) equipped with a Zeiss Axiocam HRc digital camera. The size of a minimum of 30 cells was measured using Axiovision (4.8.2 version) software at $\times 1000$ magnification. The standard deviation $( \pm)$ is provided, next to the observed mean. To observe the shape and location of the nucleus, cells were stained with 1:100,000 SYBR Green (Sigma Aldrich, St. Louis, USA) for $1 \mathrm{~min}$, and photographed using the Zeiss fluorescence microscope with a Zeiss-38 filter set (excitation BP 470/40, beam splitter FT 495, emission BP 525/50). Chloroplast autofluorescence microscopy was carried out on live cells using the above-mentioned microscope equipped with a Chroma filter cube (emission filter ET480/20x, dichromatic mirror AT505dc, suppression filter AT515lp), and digitally photographed using a Zeiss Axiocam HRc digital camera.

For scanning electron microscopy (SEM), mid-exponential batch cultures of strains TIO606, TIO896 and TIO879 were concentrated by a Universal 320 R centrifuge (Hettich-Zentrifugen, Tuttlingen, Germany) at $850 \mathrm{~g}$ for $10 \mathrm{~min}$ at room temperature. Cells were fixed, dehydrated and critical point dried (K850 Critical Point Dryer, Quorum/Emitech, West Sussex, UK), sputter-coated with gold, and examined with a Zeiss Sigma FE (Carl Zeiss Inc., Oberkochen, Germany) scanning electron microscope following the procedures detailed in Luo et al., (2018). Labelling of tabulation follows a modified Kofoidian system (Fensome et al., 1993), and the sulcal 
plate labelling follows Balech (1980).

Transmission electron microscopy (TEM)

Mid-exponential batch cultures of strains TIO606, TIO896 and TIO879 were fixed in $2.5 \%$ glutaraldehyde in phosphate buffer saline (PBS, $0.1 \mathrm{M}$ at $\mathrm{pH} 7.4$ ) for $1 \mathrm{~h}$, concentrated by centrifugation and then washed three times in PBS for 10 min each. They were post-fixed in $1 \% \mathrm{OsO}_{4}$ overnight at $4{ }^{\circ} \mathrm{C}$ and washed three times in PBS for 10 min each. The cells were then dehydrated through a graded ethanol series $(10,30$, $50,70,95,3 \times$ in $100 \%, 10 \mathrm{~min}$ at each step). The pellet was embedded in LowViscosity Embedding Media (Polyscience Europe GmbH, Eppelheim, Germany) and sectioned with a Reichert Ultracut E microtome (Leica, Vienna, Austria), mounted on Formvar-coated grids, stained with uranyl acetate and lead citrate, and observed in a JEOL JEM-100 transmission electron microscope (JEOL, Tokyo, Japan).

PCR amplifications and sequencing

The total algal DNA was extracted from $10 \mathrm{~mL}$ of exponentially growing cultures using a MiniBEST Universal DNA Extraction Kit (Takara, Tokyo, Japan) according to the manufacturer's protocol. Various regions of the ribosomal RNA (rRNA) genes including the SSU rRNA, partial LSU rRNA (D1-D6) and ITS1-5.8S-ITS2 were amplified using primer pairs specified previously and following standard protocols (Luo et al., 2019). Newly obtained sequences were deposited in GenBank with accession numbers MT465325 to MT465337. 
Sequence alignment and phylogenetic analysis

Newly obtained sequences (SSU, ITS-5.8S and LSU rRNA D1-D6) were

incorporated into a systematically representative set of dinoflagellate taxa available in

GenBank. Taxon samples of Peridiniales follow Kretschmann et al. (2018b) and those

of Gonyaulacales, Dinophysales, Prorocentrales, Gymnodiniales were also included.

Noctiluca scintillans (Macartney) Kofoid \& Swezy was used as outgroup. Sequences

were aligned using MAFFT v7.110 (Katoh \& Standley, 2013) online program

(http://mafft.cbrc.jp/alignment/server/) with default settings. Alignments were

manually checked with BioEdit v. 7.0.5 (Hall, 1999). Completed alignments of ITS15.8S-ITS2 sequences were imported into MEGA6 software (Tamura et al., 2013) to estimate divergence rates using simple uncorrected pairwise (p) distance matrices. For Bayesian inference (BI), jModelTest (Posada, 2008) was used to select the most appropriate model of molecular evolution with Akaike Information Criterion (AIC). Bayesian reconstruction of the data matrix was performed using MrBayes 3.2 (Ronquist \& Huelsenbeck, 2003) with the best-fitting substitution model (GTR+G). Four Markov chain Monte Carlo (MCMC) chains ran for 4,000,000 generations, sampling every 100 generations, with an appropriate burn-in (10\%) as inferred from the evaluation of the trace files using Tracer version 1.7

(http://tree.bio.ed.ac.uk/software/tracer/). A majority rule consensus tree was created in order to examine the posterior probabilities of each clade. Maximum likelihood (ML) analyses were conducted with RaxML v7.2.6 (Stamatakis, 2006) on the T-REX web server (Boc et al., 2012) using the model GTR+G. Node support was assessed 
with 1000 bootstrap replicates.

\section{Results}

Johsia Z.Luo, Na Wang, K.N.Mertens \& H.Gu gen. nov.

DiAGNOSIS: Armoured cells with a plate formula of Po, X, 4', 2a, 6", 6C, 4S, 5"', 2"'". A stalked pyrenoid and a type B eyespot are present. There is a short and rectangular canal plate. The only known species is marine. Johsia differs from Parvodinium and Palatinus in possessing six instead of seven precingular plates and differs from Peridiniopsis in an additional apical and intercalary plate.

Etymology: The name Johsia is after Ernst Johannes Schmidt (1877-1933), who carried out the first survey on dinoflagellates in the inner Gulf of Thailand. Johs is an abbreviation of Johannes that was used by Schmidt (1901).

TYPE SPECIES: Johsia chumphonensis Z.Luo, Na Wang, K.N.Mertens \& H.Gu

Johsia chumphonensis Z.Luo, Na Wang, K.N.Mertens \& H.Gu sp. nov. (Figs 1-17)

DiAgNOSIS: Cells are 13.5-17.9 $\mu \mathrm{m}$ long and 11.0-16.2 $\mu \mathrm{m}$ wide. The cells have a rounded epitheca and hypotheca. The epitheca is 1.5 times as long as hypotheca in dorsal view. The thecae display a plate formula of Po, cp, X, 4', 2a, 6", 6C, 4S, 5'", $2^{\prime \prime \prime \prime}$. Plate $2 \mathrm{a}$ is about half the size of $1 \mathrm{a}$, leading to a slight asymmetry on the dorsal epitheca. Each cell has a single reticulated chloroplast with one multiple-stalked 
pyrenoid. A type B eyespot comprises two rows of lipid globules within a chloroplast with one row of crystals overlying the eyespot. The nucleus is elongated and located posteriorly.

HolOTYPE: A SEM stub from strain TIO606 designated as 243490 and deposited at Beijing Museum of Natural History, China.

TyPE LOCALITY: Off Chumphon, Gulf of Thailand (99 $\left.25^{\prime} 10.54^{\prime \prime} \mathrm{E}, 10^{\circ} 29^{\prime} 40.15^{\prime \prime} \mathrm{N}\right)$; collected by Haifeng Gu on August 21 2018; temperature: $28.5^{\circ} \mathrm{C}$, salinity: 33 .

ETYMOLOGY: The epithet chumphonensis is derived from Chumphon, the town close to the type locality.

DistRIBUTION: Gulf of Thailand, Hainan (China), Manado (Indonesia), Okinawa (Japan) and Philippines.

GENBANK ACCESSION NUMBER SEQUENCES: MT465325 (SSU rRNA), MT465333 (LSU rRNA) and MT465329 (ITS-5.8S rRNA) of strain TIO606.

\section{Description}

Flagellated cells of Johsia chumphonensis swam slowly and spun continuously.

Motile (=vegetative) cells often shed parent thecae and naked cells exited through a slit in the hypotheca (Fig. 1). Binary fission took place through eleutheroschisis (Fig. 2) and each daughter cell developed a new theca again. Non-motile cells with a diameter of $11.3-16.6 \mu \mathrm{m}(14.4 \pm 1.5 \mu \mathrm{m}, \mathrm{n}=20)$ were formed upon stress (Fig. 3), from which motile cells emerged through an undetermined opening after 
approximately $36 \mathrm{~h}$ (Fig. 4). Resting cysts formed spontaneously in culture. They were generally spherical (Fig. 5, Figs S1, S2) with a diameter of 17.8-22.0 $\mu \mathrm{m}(19.7$ $\pm 1.4 \mu \mathrm{m}, \mathrm{n}=30$ ), but could be ovoid sometimes. The cysts had a brown, smooth and thick wall and were full of granules (Fig. 5). Paratabulation was observed on some cysts (Fig. 6). Sixty newly formed cysts were isolated for germination but only six of them germinated after around two to five days. The archeopyle could not be observed. Motile cells of $J$. chumphonensis strain TIO606 were 13.5-17.9 $\mu \mathrm{m}$ long (15.6 \pm 1.2 $\mu \mathrm{m}, \mathrm{n}=30)$ and $11.0-16.2 \mu \mathrm{m}$ wide $(14.2 \pm 1.1 \mu \mathrm{m}, \mathrm{n}=30)$. Small cells approximately half the size of vegetative cells were observed (Fig. S3). The cells had a rounded epitheca and hypotheca with a much larger epitheca (Figs 1, 7). There was a round pyrenoid surrounded by starch in the epicone and one pronounced orange eyespot in the sulcal area (Figs 7,8). There was a single chloroplast forming a network in the periphery of the motile cells (Fig. 9). The nucleus was rounded to elongated and located posteriorly ('N' in Fig. 8 and Fig. S4). The thecal plates were smooth with sometimes pores visible on the outer surface (Fig. 15), although internal views revealed the presence of numerous pores ca. $0.27 \mu \mathrm{m}$ in diameter (Fig. 12). Plates $1^{\prime}$ and $3^{\prime}$ were six-sided and were nearly symmetrical (Figs 10, 11). Plates $2^{\prime}$ and $4^{\prime}$ were seven-sided (Fig. 11). Plate 3' did not contact plate 4" in all 34 cells examined. Plate $2 \mathrm{a}$ was pentagonal and about half the size of the six-sided 1a (Figs 11, 12). The third precingular plate was four-sided, whereas the others were five-sided (Figs 11,13$)$. The cingulum was $2.0-3.2 \mu \mathrm{m}$ wide $(2.5 \pm 0.4 \mu \mathrm{m}, \mathrm{n}=17)$, situated in the lower part of the cell and descended (levorotary) ca. its width (Fig. 10). The 
cingular plates were similar in size except $\mathrm{C} 1$ was relatively smaller (Figs 10, 15). The apical pore complex was tear-shaped comprising a round pore plate (Po), a round apical pore, a cover plate (cp) and a short rectangular canal plate (X) (Fig. 12). Plates $2^{\prime \prime \prime}$ and 4 "' were four-sided whereas the other postcingular plates were five-sided (Fig. 14). The antapical plates (1"'"', $\left.2^{\prime \prime \prime \prime}\right)$ were five-sided and similar in size (Fig. 14). The sulcus comprised four sulcal plates (Figs 10, 15). Schematic drawings showing the plate pattern of J. chumphonensis are provided in Figs S5-S8.

Longitudinal sections through the cells of strain TIO606 showed a posteriorly located nucleus, a multiple-stalked pyrenoid in the epitheca, and marginal chloroplast lobes (Fig. 16). The eyespot comprised two rows of 20-30 lipid globules with one row of elongated crystals overlying the eyespot (Fig. 17). The lipid globules were $75-120 \mathrm{~nm}$ in diameter.

Parvodinium parvulum (Wołoszyńska) Na Wang, K.N.Mertens \& H.Gu comb. nov. (Figs 18-23)

BASIONYM: Peridinium parvulum Wołoszyńska. [1930. Arch. Hydrobiol. Rybactwa 5, p. 168, fig. 6].

LECTOTYPE, designated here: An illustration of the cell in ventral view in Wołoszyńska (1930: p. 168, fig. 6i), and reproduced here (Fig. S9). The type locality is Java, Indonesia.

Flagellated cells of strain TIO879 were 14.1-24.2 $\mu \mathrm{m}$ long $(19.8 \pm 2.4 \mu \mathrm{m}, \mathrm{n}=46)$ and $12.7-21.1 \mu \mathrm{m}$ wide $(16.8 \pm 2.3 \mu \mathrm{m}, \mathrm{n}=46)$. The cells had a conical epitheca and 
a rounded hypotheca (Figs S10, S11). There were numerous ribbon-like chloroplasts radiating from the center to the periphery of the cell ('c' in Figs S11, S12). The nucleus was elongated and located posteriorly ('N' in Fig. S13). Coccoid cells, possibly ecdysal stages, were mostly ellipsoid (Fig. S14), 17.7-25.8 $\mu \mathrm{m}$ long (23.0 \pm $2.2 \mu \mathrm{m}, \mathrm{n}=23), 10.5-16.2 \mu \mathrm{m}$ wide $(14.5 \pm 1.5 \mu \mathrm{m}, \mathrm{n}=23)$ but could be spherical as well (Fig. S15). Neither divisions nor rejuvenation of coccoid cells were observed.

The thecae had a plate formula of Po, cp, X, 4', 2a, 7", 6C, 5S, 5"', 2"'"' (Figs 1823). The epitheca: hypotheca length ratio on the dorsal side was $1.4-2.0(1.89 \pm 0.43$, $\mathrm{n}=10$ ). The thecal plates displayed a polygonal reticulation formed of dots. Some thecal plates bore papillae on the hypotheca (Fig. 22). The arrangement of the epithecal plates was symmetric and showed the conjunctum tabulation type. Plate $1^{\prime}$ was six-sided and nearly symmetrical (Fig. 18). Plates $2^{\prime}$ and $4^{\prime}$ were seven-sided and similar in size (Figs 19, 20). There were two five-sided anterior intercalary plates (1a and 2a) of similar size (Fig. 21). There were seven precingular plates, the third and fifth of which were four-sided and the fourth was six-sided (observed in 33 cells), whereas the others were five-sided (Figs 18-20). The cingulum was 2.0-3.1 $\mu \mathrm{m}$ wide $(2.7 \pm 0.3 \mu \mathrm{m}, \mathrm{n}=11)$, situated in the lower part of the cell and descended ca. half its width (Fig. 23). The cingulum comprised six plates of similar size (Figs 18, 19). The apical pore complex was tear-shaped comprising a round pore plate $(\mathrm{Po})$, a round apical pore, a cover plate (cp) and an elongated canal plate (X) (Fig. 21). Plates 2"' and $3^{\prime \prime \prime}$ were five-sided whereas the other postcingular plates were four-sided (Fig. 
22). The first antapical plate was about half the size of plate $2^{\prime \prime \prime \prime}$ (Fig. 22). The sulcus comprised five sulcal plates (Figs 22, 23).

Longitudinal sections through the vegetative cells of strain TIO879 showed an elongate nucleus situated posteriorly, many ribbon-like chloroplasts radiating from the center to the periphery and many starch grains (Fig. S16). An eyespot was observed in the sulcal region located within a chloroplast lobe comprising four rows of $\sim 120$ lipid globules (Fig. S17). The lipid globules were $40-80 \mathrm{~nm}$ in diameter.

\section{Molecular analysis and phylogeny}

For SSU and LSU (D1-D6) rRNA sequences comparison among Johsia

chumphonensis strains and Parvodinium species, the sequence similarities were above 99.49\% (Table S2). The sequence similarities and genetic distances based on ITS5.8S rRNA sequences ranged from $96.9 \%$ to $100 \%$ and were less than 0.04 between strains of J. chumphonensis (Table S3). The sequence similarities and genetic distances based on ITS-5.8S rRNA sequences were greater than $69.7 \%$ and less than 0.32 between Parvodinium strains (Table S4).

The maximum likelihood (ML) and Bayesian inference (BI) analysis based on concatenated SSU, ITS-5.8S and partial LSU rRNA sequences yielded similar phylogenetic trees. The BI tree is illustrated in Fig. 24. The family Peridiniopsidaceae comprised the genera Johsia, Peridiniopsis, Palatinus and Parvodinium with strong Bayesian posterior probability (0.99 BPP) and high ML bootstrap support (100 BS), which formed a sister clade of the family Peridiniaceae and genera Vulcanodinium 
and Caladoa Z.Luo, K.N.Mertens \& H.Gu with low support ( $<0.9$ BPP/78 BS). There were two sister clades within family Peridiniopsidaceae. One of them comprised genera Johsia, Peridiniopsis, Palatinus and the other consisted of Parvodinium. The genus Johsia was monophyletic with maximal support (1.0 BPP/100 BS), which was the sister clade of Peridiniopsis borgei and the strain UTEX1948 identified as "Scrippsiella" hexapraecingula with maximal support. Together, they formed a sister clade to Palatinus with strong support (0.91 BPP/100 BS). Parvodinium was monophyletic as well with strong Bayesian posterior probability (0.99 BPP) and high ML bootstrap support (100 BS). There were two sister clades within Parvodinium. One of them included P. umbonatum only and another comprised other Parvodinium species with maximal support. Parvodinium parvulum strain TIO879 was the sister clade of Parvodinium inconspicuum (Lemmermann) Carty (GenBank accession number: FR865631) and Parvodinium elpatiewskyi (Ostenfeld) Kretschmann, Zerdoner \& Gottschling (GenBank accession number: MN604293) with maximal support. They formed a sister clade of Parvodinium trawinskii Kretschmann, Owsianny, Zerdoner \& Gottschling and Parvodinium mixtum Kretschmann, Owsianny, Zerdoner \& Gottschling with maximal support. In addition, they formed a sister clade of Parvodinium marciniakii Kretschmann, Owsianny, Zerdoner \& Gottschling with maximal support. 


\section{Discussion}

\section{Johsia chumphonensis}

Strain TIO606 has an unusual epitheca that is otherwise found only in species of Durinskia Carty \& El.R.Cox (Yamada et al., 2017; Kretschmann et al., 2018c), some pfiesterians e.g., Aduncodinium glandulum N.S.Kang, H.J.Jeong, \& Moestrup, Luciella masanensis P.L.Mason, H.J.Jeong, Litaker, Reece \& Steidinger (Mason et al., 2007; Kang et al., 2015), Heterocapsa steinii Tillmann, Gottschling, Hoppenrath, Kusber \& Elbrächter (Tillmann et al., 2017) and Bagredinium crenulatum (Couté \& A.Iltis) K.P.Da, Zongo, Mascarell \& Couté (Da et al., 2004). In the published molecular trees, the phylogenetic positions of these species are always nested within their corresponding species groups. Strain TIO606 shares similar morphology with Durinskia but the latter has five cingular plates instead of six (Carty \& Cox, 1986). Strain TIO606 differs from Parvodinium and Palatinus in possessing six instead of seven precingular plates, from Peridiniopsis in possessing an additional apical and intercalary plate. Strain TIO606 also differs from Peridinium in the number of cingular plates (6C vs $5 \mathrm{C}$ ) and anterior intercalary plates (2a vs $3 a)$, from Thompsodinium Bourrelly in the number of anterior intercalary plates (2a vs 3a) (Bourrelly, 1968; Carty, 1989), and from "Scrippsiella" hexapraecingula in the loss of one intercalary plate (Horiguchi \& Chihara, 1983). The freshwater species Bagredinium crenulatum has only five cingular plates and different sizes of the intercalaries (Da et al., 2004). 
Heterocapsa steinii shares identical plate pattern with that of strain TIO606 except that the former has five sulcal plates instead of four in the latter (Tillmann et al., 2017). Moreover, H. steinii has a large anterior sulcal plate deeply intruding the epitheca, which is similar in height to its other precingular plates. Strain TIO606 has a large anterior sulcal plate as well, but it does not intrude the epitheca as deep as in Heterocapsa steinii. In addition, Heterocapsa steinii lacks an eyespot (Tillmann et al., 2017).

Considering the rare plate pattern, two unequal anterior intercalary plates as well as a type B eyespot, we erect a new genus Johsia to incorporate strain TIO606 and related strains. Johsia chumphonensis is reported from the Gulf of Thailand, Manado of Indonesia, Hainan Island of China in the present study, as well as in Okinawa, Japan, Sribu Archipelago, Indonesia and Masinloc Bay, Philippines (Prabowo, 2015), suggesting that this species is widely distributed in subtropical and tropical waters of Asia.

\section{Attribution of strain TIO879 to Parvodinium parvulum}

Strain TIO879 fits the description of Parvodinium (Carty, 2008). However, strain TIO879 does not show any antapical protuberance, thus can be separated from Parvodinium trawinskii, P. marciniakii, Parvodinium africanum (Lemmermann) Carty, $P$. deflandrei (Lefèvre) Carty, $P$. goslaviense (Wołoszynska) Carty, $P$. marchicum Lemmermann and P. munusculum Er. Lindemann which demonstrate one to three antapical spines (Lemmermann, 1910; Wołoszyńska, 1916; Lindemann, 1918; 
Carty, 2008; Kretschmann et al., 2018b). Strain TIO879 shares unequal antapical plates with Parvodinium belizense (Carty) Carty and Parvodinium dzieduszyckii (Wołoszyńska) Moestrup (Wołoszyńska, 1916; Carty \& Wujek, 2003), but the latter two species have a more conical epitheca. Moreover, Parvodinium dzieduszyckii is much larger (34-40 $\mu \mathrm{m}$ vs 14.1-24.2 $\mu \mathrm{m}$ long) and has an equatorial cingulum. Strain TIO879 is morphologically close to Parvodinium mixtum but differs in the unequal antapical plates.

Parvodinium inconspicuum was reported to have three antapical spines and unequal antapical plates (Lemmermann, 1910), but some specimens without antapical protuberance were identified as $P$. inconspicuum as well (Hansen \& Flaim, 2007). Therefore, several species lacking antapical spines, such as Peridinium javanicum (Bernard, 1908) and Peridinium parvulum (Wołoszyńska, 1930) were postulated to be junior synonyms of Parvodinium inconspicuum (Moestrup \& Calado, 2018). However, P. inconspicuum from the localities where the type was described from Chatham Islands (New Zealand), Molokai and Oahu (Hawaii - no single locality was denoted for the type by Lemmermann, 1899) corresponding to the protologue has not been examined using modern techniques, and whether specimens of $P$. inconspicuum with variable morphology (Hansen \& Flaim, 2007) are genetically identical remain to be determined. A putative Parvodinium inconspicuum strain CCAP 1140/3 shares 98.26\% similarity with strain TIO879 in ITS-5.8S rRNA sequence, but its detailed morphology is not available (Tardio et al., 2009). Another putative Parvodinium inconspicuum strain intermingles with $P$. mixtum and P. trawinskii. These three 
species are morphologically similar but differ in the number of antapical spines.

Strain TIO879 has the same outline, growth bands, size, tabulation as Peridinium parvulum which was originally described from tropical Asia (Wołoszyńska, 1930).

Moreover, both can bear papillae on the hypotheca and the dissimilar size of the antapical plates is also very similar. Strain TIO879 differs from Peridinium javanicum (Fig. S18) and Peridinium caudatum var. morsum (Playfair) Playfair (Fig. S19) in that the latter two species have a more flattened antapex (Bernard, 1908; Playfair, 1919). However, some cells of Peridinium parvulum also have a flattened antapex (fig. 6b, Wołoszyńska, 1930), thus it might be a junior synonym of Peridinium javanicum since they are morphologically similar and described from the same area (Java Island, Indonesia); a study from the type locality would be necessary. These three species have been considered as junior synonyms of Parvodinium inconspicuum (Moestrup \& Calado, 2018) but we attribute strain TIO879 to Peridinium parvulum and transfer it to Parvodinium. To fully understand the relationship between Parvodinium parvulum and Peridinium javanicum, specimens from the type locality need to be examined carefully in the future.

\section{Coccoid cells}

Coccoid cells were observed in cultures of Parvodinium parvulum, and formed by Parvodinium marciniakii, Parvodinium trawinskii, Parvodinium mixtum, and Palatinus apiculatus (Ehrenberg) Craveiro, Calado, Daugbjerg \& Moestrup as well (Craveiro et al., 2009; Kretschmann et al., 2018a; Kretschmann et al., 2018b). Unlike 
"Scrippsiella" hexapraecingula which possesses an asexual life cycle in which a motile phase alternates with a coccoid phase in culture (Horiguchi \& Chihara, 1983), the coccoid cells of Parvodinium parvulum neither divide nor rejuvenate. Coccoid cells have also been observed for Parvodinium elpatiewskyi (Li et al., 2015, as Peridiniopsis elpatiewskyi Ostenfeld), Peridiniopsis amazonica B.Meyer (Meyer et al., 1997), Peridiniopsis borgei (Entz, 1926, as Peridinium borgei Lemmermann; Li et al., 2015, misidentified as Peridiniopsis cristata var. tubilifera Couté, Perrette \& Chomérat). These coccoid cells were encountered in the field samples and can be considered resting cysts.

The life cycle of Johsia chumphonensis appears complex. Johsia chumphonensis shed the theca through the hypothecal opening and binary division occurs outside the theca, as also reported in an unidentified Parvodinium species (Sako et al., 1986) and Peridinium sanguineum H.J.Carter (Pfiester \& Anderson, 1987). It is interesting to note that $J$. chumphonensis generate two kinds of coccoid cells in cultures differing in the size and wall thickness. Both have a dormancy period before germination thus could be considered resting cysts. The small cysts are apparently asexual but the large cysts are probably sexual as they are larger than the vegetative cells (19.7 vs 15.6 $\mu \mathrm{m}$ ). Small potential gametes were observed as reported previously (Pfiester et al., 1984; Sako et al., 1986) although sexual fusion was not observed. Sexual cysts were generated by Parvodinium inconspicuum in culture (Pfiester et al., 1984), but not detailed in Parvodinium umbonatum (Zhang et al., 2011).Cysts of Johsia chumphonensis differ from those of $P$. umbonatum and P. inconspicuum in that they 
are rounded, not pyriform to ovoid (Chu et al., 2008; Tardio et al., 2009).

\section{Eyespot}

Seven types of eyespot are known in dinoflagellates, including the complex ocelloid of the Warnowiaceae (Greuet, 1987; Moestrup \& Daugbjerg, 2007; Craveiro et al., 2010). Type A is characterized by one to several layers of opaque globules inside a chloroplast. Type B is similar to type A except an additional overlying vesicle containing crystal-like structures. The eyespot of $J$. chumphonensis is located within the chloroplast and consists of two rows of lipid globules with one row of elongated crystals overlying, and thus was identified as a type B eyespot. In contrast, the eyespot of Parvodinium parvulum consists of four rows of lipid globules without overlying crystals, thus was identified as a type A eyespot. A prominent eyespot has been reported in other Parvodinium species (Kretschmann et al., 2018b), but this is the first time that a type A eyespot is confirmed. This is consistent with the finding of a type A eyespot in other species of family Peridiniopsidaceae, such as Palatinus apiculatus (Craveiro et al., 2009). A type B eyespot in J. chumphonensis is not surprising since a type B eyespot was also reported in Peridiniopsis borgei (Calado \& Moestrup, 2002) and both types may occur in species of the same genus such as Bysmatrum (Dawut et al., 2018; Luo et al., 2018). A type A eyespot was also reported in Peridinium cinctum, the type species of family Peridiniaceae (Spector \& Triemer, 1979), supporting its systematic significance at family or higher taxonomic level (Lindberg et al., 2005). Likewise, a type C, D and E eyespot was reported exclusively in 
Tovelliaceae, Kryptoperidiniaceae and Suessiales (Moestrup \& Daugbjerg, 2007).

\section{Phylogenetic positions of marine Johsia and "Scrippsiella" hexapraecingula}

The family Peridiniopsidaceae now includes genera Parvodinium, Palatinus, Peridiniopsis and Johsia as well. However, the strain UTEX1948 identified as "Scrippsiella" hexapraecingula collected from a tide-pool of Los Angeles, USA is also nested within the Peridiniopsidaceae (Kretschmann et al., 2018a; present study). The strain UTEX1948 was originally identified as Peridinium sociale (Henneguy) Biecheler (Starr, 1978), but later it was reexamined and believed to be close to "Scrippsiella" hexapraecingula which has three anterior intercalary plates (Horiguchi \& Chihara, 1983). "Scrippsiella" hexapraecingula has six precingular plates and a type A eyespot in the sulcal area (Horiguchi \& Chihara, 1983; Horiguchi et al., 1999). Instead Scrippsiella usually has seven precingular plates (Gottschling et al., 2005; Luo et al., 2016), therefore, a new name might be needed to incorporate "Scrippsiella" hexapraecingula. "Scrippsiella" hexapraecingula is comparably closely related to Johsia in the molecular phylogeny, which is consistent with the fact that they share six precingular plates compared to seven in Palatinus and Parvodinium (Fig. 24).

The marine-freshwater boundary is a barrier in the evolutionary diversification of dinoflagellates but marine-to-freshwater transitions are now considered frequent in dinoflagellates (Čalasan et al., 2019). Peridiniopsidaceae was reported to originate prior to the Cretaceous-Paleogene boundary and its diversification may have started in the late Cretaceous (Čalasan et al., 2019). It is interesting to note that the marine 
Johsia chumphonensis and "Scrippsiella" hexapraecingula are nested within the mainly freshwater Peridiniopsidaceae. Re-colonization of marine water by Johsia chumphonensis and "Scrippsiella" hexapraecingula is possible, considering that both have a coccoid phase (Horiguchi \& Chihara, 1983; present study), which may help them to survive the transition. A recent transition was reported for Huia caspica, which is known to inhabit both marine and freshwater (Gu et al., 2016).

Acknowledgements

We thank Marc Gottschling, Mona Hoppenrath, Øjvind Moestrup and an anonymous reviewer for constructive suggestions that improved the manuscript greatly. Xinqing Zheng and Nengwang Chen were thanked for sampling in Indonesia and the freshwater reservoir of Fuzhou, China.

Funding

This work was supported by National Natural Science Foundation of China (41676117), Scientific Research Foundation of Third Institute of Oceanography, MNR (2019018), China-ASEAN Maritime Cooperation Fund and the National Programme on Global Change and Air-Sea Interaction. 


\section{Author contributions}

Z. Luo: microscopy, drafting and editing manuscript; K. N. Mertens: drafting and editing manuscript; H. Gu: original concept, drafting and editing manuscript; N. Wang: microscopy, sequencing and editing manuscript; Yiran Wu: sampling, editing manuscript; P. Uttayarnmanee: sampling and editing manuscript; M. Pransilpa: sampling, editing manuscript; K. A. Roeroe: sampling, editing manuscript.

\section{References}

Angles, S., Rene, A., Garces, E., Lugliè, A., Sechi, N., Camp, J. \& Satta, C.T. (2017). Morphological and molecular characterization of Bysmatrum subsalsum (Dinophyceae) from the western Mediterranean Sea reveals the existence of cryptic species. Journal of Phycology, 53: 833-847.

Balech, E. (1980). On the thecal morphology of dinoflagellates with special emphasis on circular and sulcal plates. Anales del Centro de Ciencias del Mar y Limnologia, Universidad Nacional Autonomia de Mexico, 7: 57-68.

Bernard, C. (1908). Protococcacées et Desmidiées d'eau douce, récoltées à Java et décrites par Ch. Bernard. Landsdrukkerij, Batavia. Département de l’Agriculture aux Indes Néerlandaises, 230 pp.

Boc, A., Diallo, A.B. \& Makarenkov, V. (2012). T-REX: a web server for inferring, validating and visualizing phylogenetic trees and networks. Nucleic Acids 
Research, 40: W573-W579.

Bourrelly, P. (1968). Notes sur les Péridiniens d'eau douce. Protistologica, 4: 5-14.

Calado, A., Hansen, G. \& Moestrup, Ø. (1999). Architecture of the flagellar apparatus and related structures in the type species of Peridinium, $P$. cinctum (Dinophyceae). European Journal of Phycology, 34: 179-191.

Calado, A.J. \& Moestrup, Ø. (2002). Ultrastructural study of the type species of Peridiniopsis, Peridiniopsis borgei (Dinophyceae), with special reference to the peduncle and flagellar apparatus. Phycologia, 41: 567-584.

Čalasan, A.Ž., Kretschmann, J. \& Gottschling, M. (2019). They are young, and they are many: dating freshwater lineages in unicellular dinophytes. Environmental Microbiology, 21(11): 4125-4135.

Carty, S. (1989). Thompsodinium and two species of Peridiniopsis (Dinophyceae): Taxonomic notes based on scanning electron micrographs. Transactions of the American Microscopical Society, 108: 64-73.

Carty, S. \& Cox E.R. (1986). Kansodinium gen. nov. and Durinskia gen. nov.: two genera of freshwater dinoflagellates (Pyrrhophyta). Phycologia, 25: 197-204.

Carty, S. \& Wujek, D.E. (2003). A new species of Peridinium and new records of dinoflagellates and silica-scaled chrysophytes from Belize. Caribbean Journal of Science, 39(1): 136-139.

Carty, S. (2008). Parvodinium gen. nov. for the Umbonatum group of Peridinium 
(Dinophyceae). Ohio Journal of Science, 108: 103-107.

Chu, G., Sun, Q., Rioual, P., Boltovskoy, A., Liu, Q., Sun, P., Han, J. \& Liu, J. (2008). Dinocyst microlaminations and freshwater "red tides" recorded in Lake Xiaolongwan, northeastern China. Journal of Paleolimnology 39(3): 319-333.

Craveiro, S., Calado, A.J., Daugbjerg, N. \& Moestrup, Ø. (2009). Ultrastructure and LSU rDNA-based revision of Peridinium group palatinum (Dinophyceae) with the description of Palatinus gen. nov. Journal of Phycology, 45: 1175-1194.

Craveiro, S.C., Moestrup, Ø., Daugbjerg, N. \& Calado, A.J. (2010). Ultrastructure and large subunit rDNA-based phylogeny of Sphaerodinium cracoviense, an unusual freshwater dinoflagellate with a novel type of eyespot. Journal of Eukaryotic Microbiology, 57: 568-585.

Craveiro, S.C., Daugbjerg, N., Moestrup, Ø. \& Calado, A.J. (2016). Studies on Peridinium aciculiferum and Peridinium malmogiense (= Scrippsiella hangoei): comparison with Chimonodinium lomnickii and description of Apocalathium gen. nov. (Dinophyceae). Phycologia, 56: 21-35.

Da, P.K.P., Zongo, F., Mascarell, G. \& Coute, A. (2004). Bagredinium, a new genus of the Peridiniales (Dinophyta) of freshwater from Western Africa. Algological Studies, 111: 45-61.

Dawut, M., Sym, S.D., Suda, S. \& Horiguchi, T. (2018). Bysmatrum austrafrum sp. nov. (Dinophyceae), a novel tidal pool dinoflagellate from South Africa. Phycologia, 57: 169-178. 
Elbrächter, M. \& Meyer, B. (2001). Plate pattern variability and plate overlap in a clonal culture of the freshwater dinoflagellate Peridinium umbonatum Stein species complex (Dinophyceae). Neues Jahrbuch für Geologie und Paläontologie/Abhandlungen, 219(1/2): 221-227.

Entz, G. (1926): Beiträge zur Kenntnis der Peridineen. 1. Zur Morphologie und Biologie von Peridinium borgei Lemmermann.Archiv für Protistenkunde, 56: $397-447$.

Fensome, R.A., Taylor, F.J.R., Norris, G., Sarjeant, W.A.S., Wharton, D.I. \& Williams, G.L. (1993). A classification of fossil and living dinoflagellates. Micropaleontology Special Publication, 7: 1-245.

Gómez, F. (2012). A checklist and classification of living dinoflagellates (Dinoflagellata, Alveolata). CICIMAR Oceánides, 27: 65-140.

Gottschling, M., Knop, R., Plötner, J., Kirsch, M., Willems, H. \& Keupp, H. (2005). A molecular phylogeny of Scrippsiella sensu lato (Calciodinellaceae, Dinophyta) with interpretations on morphology and distribution. European Journal of Phycology, 40: 207-220.

Gottschling, M., Kretschmann, J. \& Čalasan, A.Ž. (2017). Description of Peridiniopsidaceae, fam. nov. (Peridiniales, Dinophyceae). Phytotaxa, 299: 293-296.

Greuet, C. (1987). Complex organelles. In The Biology of Dinoflagellates (Taylor, F.J.R., editor), 119-142. Blackwell press, Oxford. 
Gu, H., Mertens, K.N. \& Liu, T. (2016). Huia caspica gen. \& comb. nov., a dinoflagellate species that recently crossed the marine-freshwater boundary. Phycological Research, 64: 251-258.

Guillard, R.R.L. \& Ryther, J.H. (1962). Studies of marine planktonic diatoms. I. Cyclotella nana Hustedt and Detonula confervacea Cleve. Canadian Journal of Microbiology, 8: 229-239.

Hall, T.A. (1999). BioEdit: a user-friendly biological sequence alignment editor and analysis program for Windows 95/98/NT. pp. 95-98.

Hansen, G. \& Flaim, G. (2007). Dinoflagellates of the Trentino Province, Italy. Journal of Limnology, 66: 107-141.

Horiguchi, T. \& Chihara, M. (1983). Scrippsiella hexapraecingula sp. nov. (Dinophyceae), a tide pool dinoflagellate from the Northwest Pacific. Journal of Plant Research, 96: 351-358.

Horiguchi, T., Kawai, H., Kubota, M., Takahashi, T. \& Watanabe, M. (1999). Phototactic responses of four marine dinoflagellates with different types of eyespot and chloroplast. Phycological Research, 47(2): 101-107.

Kang, N.S., Jeong, H.J., Moestrup, Ø., Jang, T.Y., Lee, S.Y. \& Lee, M.J. (2015). Aduncodinium gen. nov. and A. glandula comb. nov. (Dinophyceae, Pfiesteriaceae), from coastal waters off Korea: Morphology and molecular characterization. Harmful Algae, 41: 25-37. 
Katoh, K. \& Standley, D.M. (2013). MAFFT multiple sequence alignment software version 7: improvements in performance and usability. Molecular Biology and Evolution, 30: 772-780.

Kretschmann, J., Čalasan, A.Ž., Kusber, W. H. \& Gottschling, M. (2018a). Still curling after all these years: Glenodinium apiculatum Ehrenb. (Peridiniales, Dinophyceae) repeatedly found at its type locality in Berlin (Germany). Systematics and Biodiversity, 16: 200-209.

Kretschmann, J., Owsianny, P.M., Čalasan, A.Ž. \& Gottschling, M. (2018b). The hot spot in a cold environment: Puzzling Parvodinium (Peridiniopsidaceae, Peridiniales) from the Polish Tatra mountains. Protist, 169: 206-230.

Kretschmann, J., Čalasan, A. Ž. \& Gottschling, M. (2018c). Molecular phylogenetics of dinophytes harboring diatoms as endosymbionts (Kryptoperidiniaceae, Peridiniales), with evolutionary interpretations and a focus on the identity of Durinskia oculata from Prague. Molecular Phylogenetics and Evolution, 118: $392-402$.

Kretschmann, J., Čalasan, A.Ž. \& Gottschling, M. (2019). Zero intercalary plates in Parvodinium (Peridiniopsidaceae, Peridiniales) and phylogenetics of $P$. elpatiewskyi, comb. nov. Protist, 125700.

Lemmermann, E.J. (1899). Ergebnisse einer Reise nachi dem Pacifific. (H. Schauinsland 1896/97.) Planktonalgen. Abh Naturw Ver Bremen :313-398. Lemmermann, E.J. (1910). Algen I (Schizophyceen, Flagellaten, Peridineen). 
Kryptogamenflora der Mark Brandenburg, Bd. 3. Gebrüder Borntraeger, Leipzig, 712 pp.

Li, Z., Shin,H.H., Lee, T., Han, M.S. (2015). Resting stages of freshwater algae from surface sediments in Paldang Dam Lake, Korea. Nova Hedwigia, 101(3-4): $475-500$.

Lindberg, K., Moestrup, Ø. \& Daugbjerg, N. (2005). Studies on woloszynskioid dinoflagellates I: Woloszynskia coronata re-examined using light and electron microscopy and partial LSU rDNA sequences, with description of Tovellia gen. nov. and Jadwigia gen. nov. (Tovelliaceae fam. nov.). Phycologia, 44: $416-440$.

Lindemann, E. (1918). Untersuchungen über Süßwasserperidineen und ihre Variationsformen. Archiv für Protistenkunde, 39: 209-262.

Liu, G., Hu, S., Chu, G. \& Hu, Z. (2008). Study on freshwater genus Peridinium (Dinophyta) from China. Journal of Systematics and Evolution, 46(5): 754771.

Luo, Z., Mertens, K.N., Bagheri, S., Aydin, H., Takano, Y., Matsuoka, K., McCarthy, F.M. \& Gu, H. (2016). Cyst-theca relationship and phylogenetic positions of Scrippsiella plana sp. nov. and S. spinifera (Peridiniales, Dinophyceae). European Journal of Phycology, 51: 188-202.

Luo, Z., Lim, Z.F., Mertens, K.N., Gurdebeke, P., Bogus, K., Carbonell-Moore, C., Vrielinck, H., Leaw, C.P., Lim, P.T., Chomerat, N., Li, X. \& Gu, H. (2018). 
Morpho-molecular diversity and phylogenetic relationship of Bysmatrum species (Dinophyceae) from the South China Sea and France. European Journal of Phycology, 53: 318-335.

Luo, Z., Mertens, K.N., Nézan, E., Gu, L., Pospelova, V., Thoha, H. \& Gu, H. (2019). Morphology, ultrastructure and molecular phylogeny of cyst-producing Caladoa arcachonensis gen. et sp. nov. (Peridiniales, Dinophyceae) from France and Indonesia. European Journal of Phycology, 54: 235-248.

Mason, P. L., Litaker, R. W., Jeong, H.J., Ha, J.H., Reece, K.S., Stokes, N.A., Park, J.Y., Steidinger, K.A., Vandersea, M.W. \& Kibler, S. (2007). Description of a new genus of Pfiesteria-like dinoflagellate, Luciella gen. nov. (Dinophyceae), including two new species: Luciella masanensis sp. nov. and Luciella atlantis sp. nov. Journal of Phycology, 43(4): 799-810.

Mertens, K., Rengefors, K., Ellegaard, M. \& Moestrup, Ø. (2012). A review of recent freshwater dinoflagellate cysts: taxonomy, phylogeny, ecology and palaeocology. Phycologia, 51: 612-619.

Meyer, B., Rai,H. \& Cronberg, G. (1997). The thecal structure of Peridiniopsis amazonica spec. nov. (Dinophyceae), a new cyst-producing freshwater dinoflagellate from Amazonian floodplain lakes. Nova Hedwigia, 65(1): 365376.

Moestrup, Ø. \& Calado, A.J. (2018). Dinophyceae. In Freshwater Flora of Central Europe (Büdel, B., Gärtner, G., Krienitz, L. \& Schagerl, M., editors), 6: 1- 
560. Springer, Berlin.

Moestrup, Ø. \& Daugbjerg, N. (2007). On dinoflagellate phylogeny and classification. In Unravelling the algae: the past, present, and future of algal systematics (Brodie, J \& Lewis, J., editors), 215-230. CRC Press, Florida.

Prabowo, D.A. (2015). Taxonomy, morphology and molecular phylogeny of several marine benthic dinoflagellates from the coastal areas of Okinawa Prefecture, Japan. University of the Ryukyus, $\mathrm{PhD}$ thesis.

Pfiester, L.A., Timpano, P., Skvarla, J.J. \& Holt, J.R. (1984). Sexual reproduction and meiosis in Peridinium inconspicuum Lemmermann (Dinophyceae). American Journal of Botany, 71(8): 1121-1127.

Pfiester, L. \& Anderson D. (1987). Dinoflagellate reproduction. In The biology of dinoflagellates. Botanical monographs vol. 21 (Taylor, F.J.R., editor), 611648. Blackwell Scientifific Publications, Oxford.

Playfair, G.I. (1919) Peridineae of New South Wales. Proceedings of the Linnaean Society of New South Wales, 44: 793-818,

Posada, D. (2008). jModelTest: phylogenetic model averaging. Molecular Biology and Evolution, 25: 1253-1256.

Raho, N., Fraga, S., Abad, J.P. \& Marín, I. (2018). Biecheleria tirezensis sp. nov. (Dinophyceae, Suessiales), a new halotolerant dinoflagellate species isolated from the athalassohaline Tirez natural pond in Spain. European Journal of 
Phycology, 53: 99-113.

Ronquist, F. \& Huelsenbeck, J.P. (2003). MrBayes 3: Bayesian phylogenetic inference under mixed models. Bioinformatics, 19: 1572-1574.

Sako, Y., Nakanishi, M., Konda, T., Ishida, Y., Kadota, H., Shrestha, K., Bhandary, H.R. \& Shrestha, R.L. (1986). Life cycle of Peridinium sp. B3 (Dinophyceae) isolated from Lake Begnas, Nepal. Bulletin of Japanese Society of Microbial Ecology, 1(1): 19-27.

Schmidt, J. (1901). Flora of Koh Chang: contributions to the knowledge of the vegetation in the Gulf of Siam. Peridiniales. Botanisk Tidsskrift, 24: 212-221.

Schnepf, E. \& Elbrächter, M. (1999). Dinophyte chloroplasts and phylogeny-A review. Grana, 38: 81-97.

Spector, D. \& Triemer, R. (1979). Ultrastructure of the dinoflagellate Peridinium cinctum f. ovoplanum. I. Vegetative cell ultrastructure. American Journal of Botany, 66: 845-850.

Stamatakis, A. (2006). RAxML-VI-HPC: maximum likelihood-based phylogenetic analyses with thousands of taxa and mixed models. Bioinformatics, 22: 26882690.

Starr, R.C. (1978). The culture collection of algae at the University of Texas at Austin. Journal of Phycology, 14(s4): 47-100.

Tamura, K., Stecher, G., Peterson, D., Filipski, A. \& Kumar, S. (2013). MEGA6: 
molecular evolutionary genetics analysis version 6.0. Molecular Biology and Evolution, 30: 2725-2729.

Tardio, M., Ellegaard, M., Lundholm, N., Sangiorgi, F. \& Giuseppe, G.D. (2009). A hypocystal archeopyle in a freshwater dinoflagellate from the Peridinium umbonatum group (Dinophyceae) from Lake Nero di Cornisello, South Eastern Alps, Italy. European Journal of Phycology, 44: 241-250.

Tillmann, U., Hoppenrath, M., Gottschling, M., Kusber, W.H. \& Elbrächter, M. (2017). Plate pattern clarification of the marine dinophyte Heterocapsa triquetra sensu Stein (Dinophyceae) collected at the Kiel Fjord (Germany). Journal of Phycology, 53: 1305-1324.

Wołoszyńska, J. (1916). Polskie Peridineae słodkowodne.-Polnische SüßwasserPeridineen. Bulletin international de l'Académie des Sciences de Cracovie, Classe des Sciences Mathématiques et Naturelles, Série B, 1915: 260-285

Wołoszyńska, J. (1930). Beitrag zur Kenntnis des Phytoplanktons tropischer Seen.Archiv für Hydrobiologie i Rybactua, 5: 159-169.

Yamada, N., Sym, S.D. \& Horiguchi, T. (2017). Identification of highly divergent diatom-derived chloroplasts in dinoflagellates, including a description of Durinskia kwazulunatalensis sp. nov. (Peridiniales, Dinophyceae). Molecular Biology and Evolution, 34(6): 1335-1351.

Zhang, Q., Liu, G. \& Hu, Z. (2011). Morphological observation of a freshwater Peridinium strain and phylogenetic analysis of Peridinium. Plant Science 
Journal, 29: 1-10.

Figs 1-9. Micrographs of Johsia chumphonensis strain TIO606. (Figs 1-5, 7-9) light microscopy. (Fig. 6) Scanning electron microscopy. Fig. 1. An empty theca showing the rupture (arrow) and a newly released athecate cell. Fig. 2. A dividing cell. Fig. 3. A small coccoid cell. Fig. 4. An empty small coccoid cell. Fig. 5. A spherical cyst showing numerous granules and an accumulation body (arrow). Fig. 6. Cyst showing paratabulation. Fig. 7. Ventral view showing a rounded epitheca and hypotheca with a prominent eyespot (arrow). Fig. 8. Dorsal view showing a ring like pyrenoid (P) and a round nucleus (N). Fig. 9. Epifluorescence image of a cell in ventral view showing the single reticulate chloroplast in the periphery of the cell. Scale bars $=5 \mu \mathrm{m}$. 


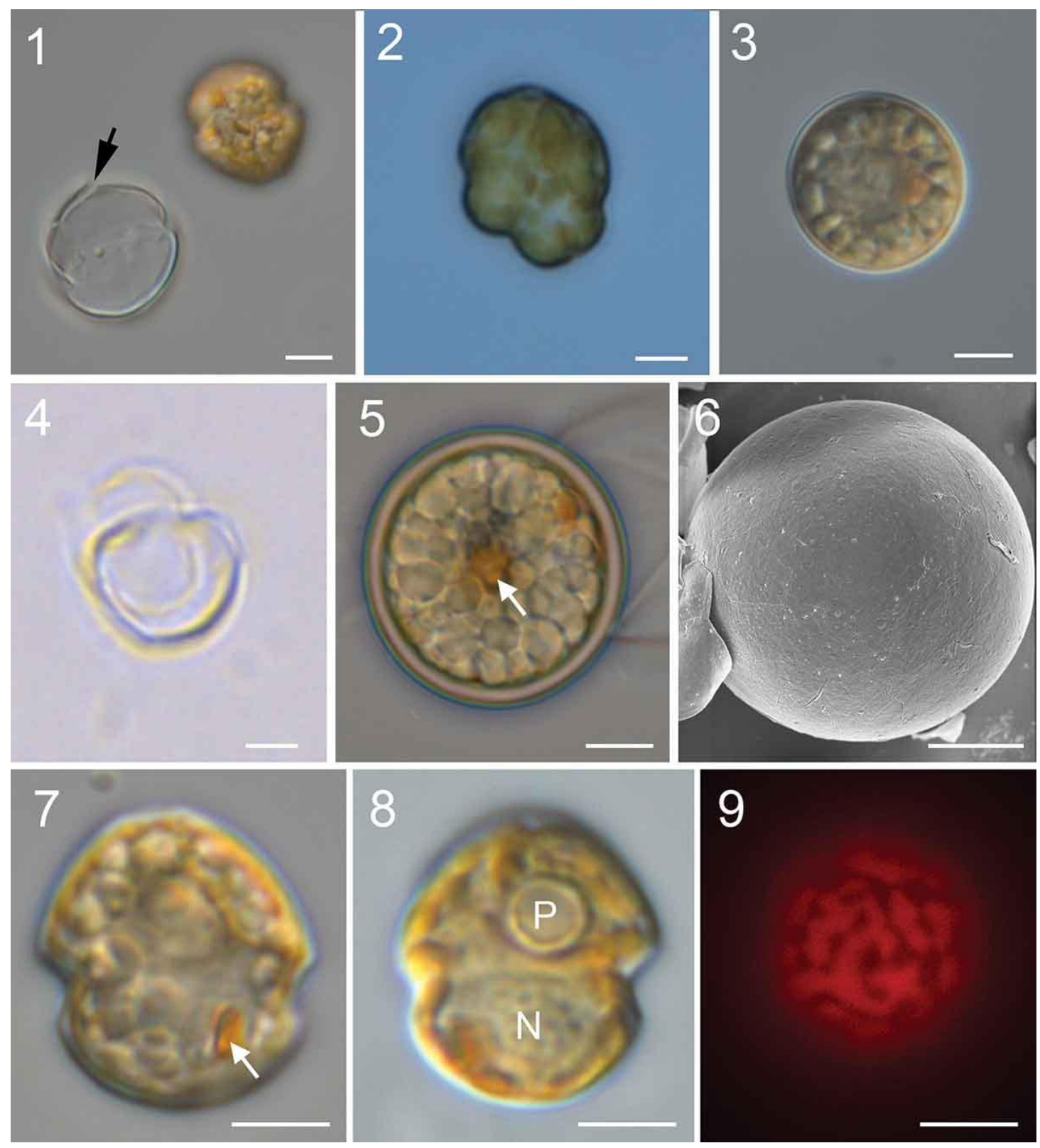

Figs 10-15. Scanning electron micrographs of vegetative cells of Johsia

chumphonensis strain TIO606. Fig. 10. Ventral view showing the first apical plate $\left(1^{\prime}\right)$, anterior sulcal plate $(\mathrm{Sa})$, posterior sulcal plate $(\mathrm{Sp})$, and three cingular plates (C1, C2, C6). Fig. 11. Apical view showing four apical plates, two anterior intercalary plates $(1 \mathrm{a}, 2 \mathrm{a})$ and six precingular plates $\left(1^{\prime \prime}-6^{\prime \prime}\right)$. Fig. 12. Internal apical view showing pore plate and canal plate (X). Fig. 13. Dorsal 
view showing two anterior intercalary plates, three precingular plates, three cingular plates and two postcingular plates (3"', 4"'). Fig. 14. Antapical view showing five postcingular plates and two antapical plates $\left(1^{\prime \prime \prime \prime}, 2^{\prime \prime \prime \prime}\right)$ of similar size. Fig. 15. Sulcal area showing Sa plate, right sulcal plate (Sd), left sulcal plate (Ss), and Sp plate. Scale bars $=5 \mu \mathrm{m}$.
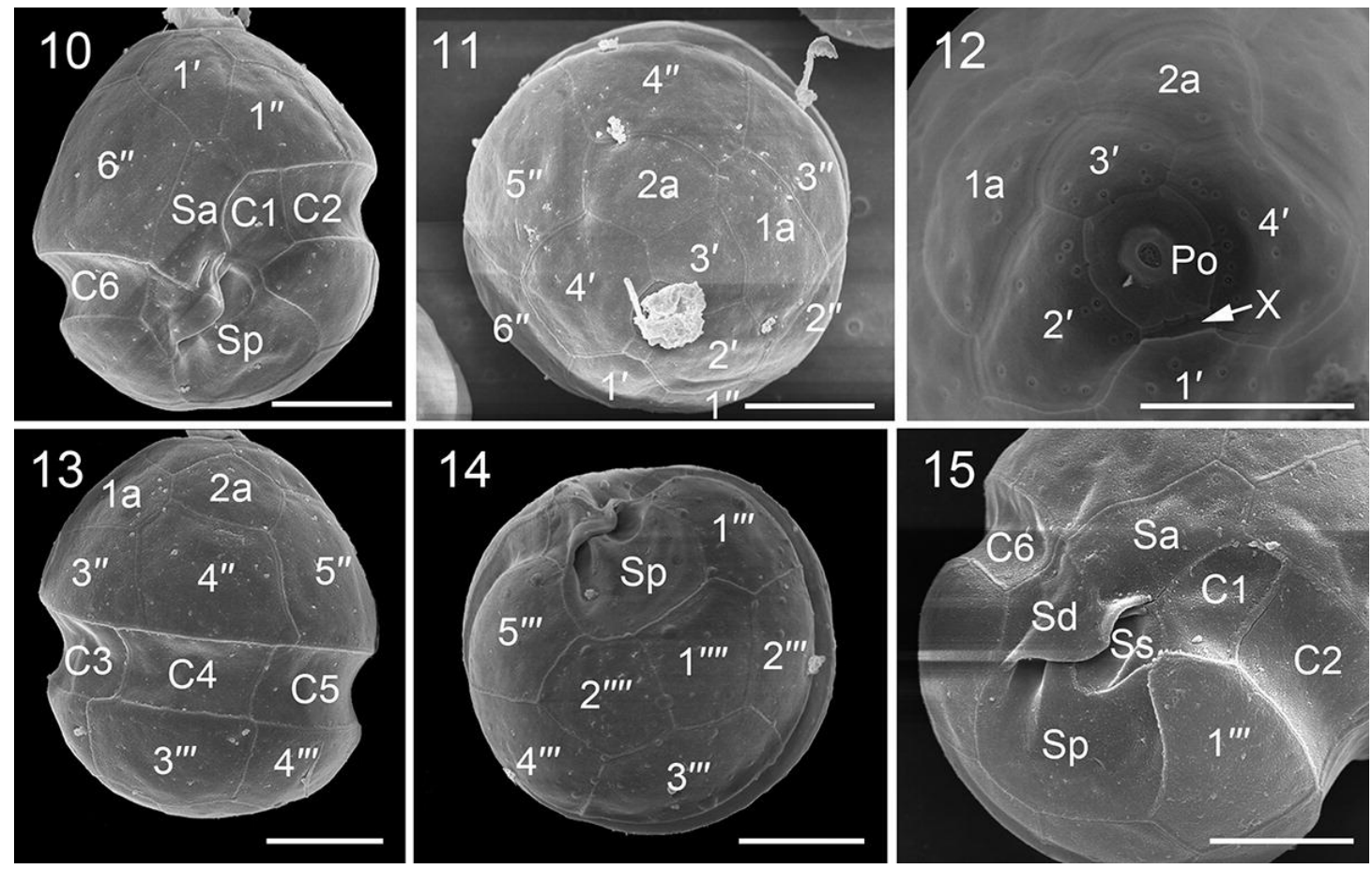

Figs 16, 17. Transmission electron micrographs of vegetative cells of Johsia chumphonensis strain TIO606. Fig. 16. Longitudinal sections through the cell showing a large nucleus $(\mathrm{N})$, a stalked pyrenoid $(\mathrm{P})$, and chloroplast lobes in the periphery of the cell (C). Fig. 17. The eyespot (e) located within a chloroplast lobe comprising two rows of globular lipids with elongated crystals overlying (arrow), neighbouring a nucleus with many chromosomes $(\mathrm{Cr})$. Scale: Fig. $16=$ $5 \mu \mathrm{m}$; Fig. $17=1 \mu \mathrm{m}$. 

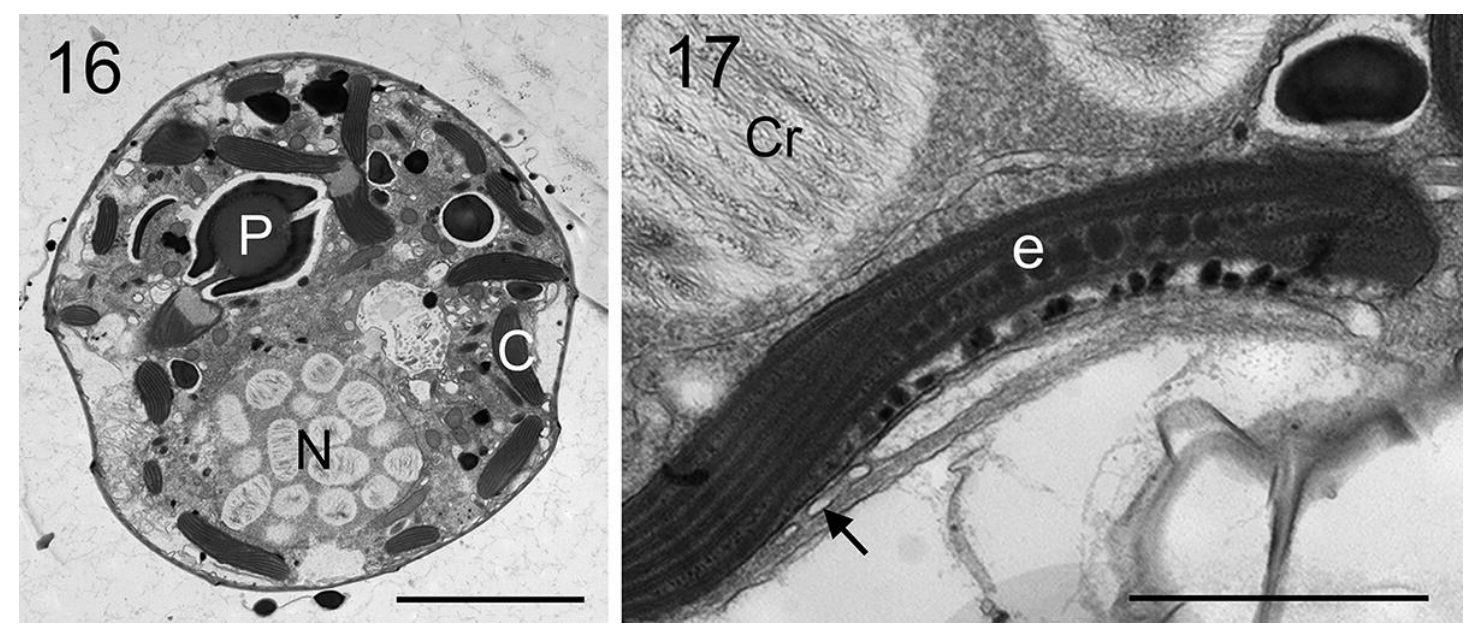

Figs 18-23. Scanning electron micrographs of vegetative cells of Parvodinium parvulum strain TIO879. Fig. 18. Ventral view showing the first apical plate, anterior sulcal plate (Sa), and three cingular plates (C1, C2, C6). Fig. 19. Dorsal view showing two anterior intercalary plates (1a, 2a), three precingular plates $\left(3^{\prime \prime}-5^{\prime \prime}\right)$, three cingular plates $(\mathrm{C} 3-\mathrm{C} 5)$ and third postcingular plate $\left(3^{\prime \prime \prime}\right)$. Fig. 20. Apical view showing three apical plates $\left(2^{\prime}-4^{\prime}\right)$, two anterior intercalary plates and six precingular plates $\left(1^{\prime \prime}-6^{\prime \prime}\right)$. Fig. 21. Apical view showing four apical plates, pore plate $(\mathrm{Po})$, cover plate $(\mathrm{cp})$, canal plate $(\mathrm{X})$ and apical pore.

Fig. 22. Antapical view showing five postcingular plates $\left(1^{\prime \prime \prime}-5^{\prime \prime \prime}\right)$, two antapical plates $\left(1^{\prime \prime \prime \prime}, 2^{\prime \prime \prime \prime}\right)$ of unequal size and numerous papillae (arrows). Fig. 23. Sulcal area showing Sa plate, $\mathrm{Sd}$ plate, Ss plate, Sm plate and Sp plate. Scale bars $=5 \mu \mathrm{m}$ 

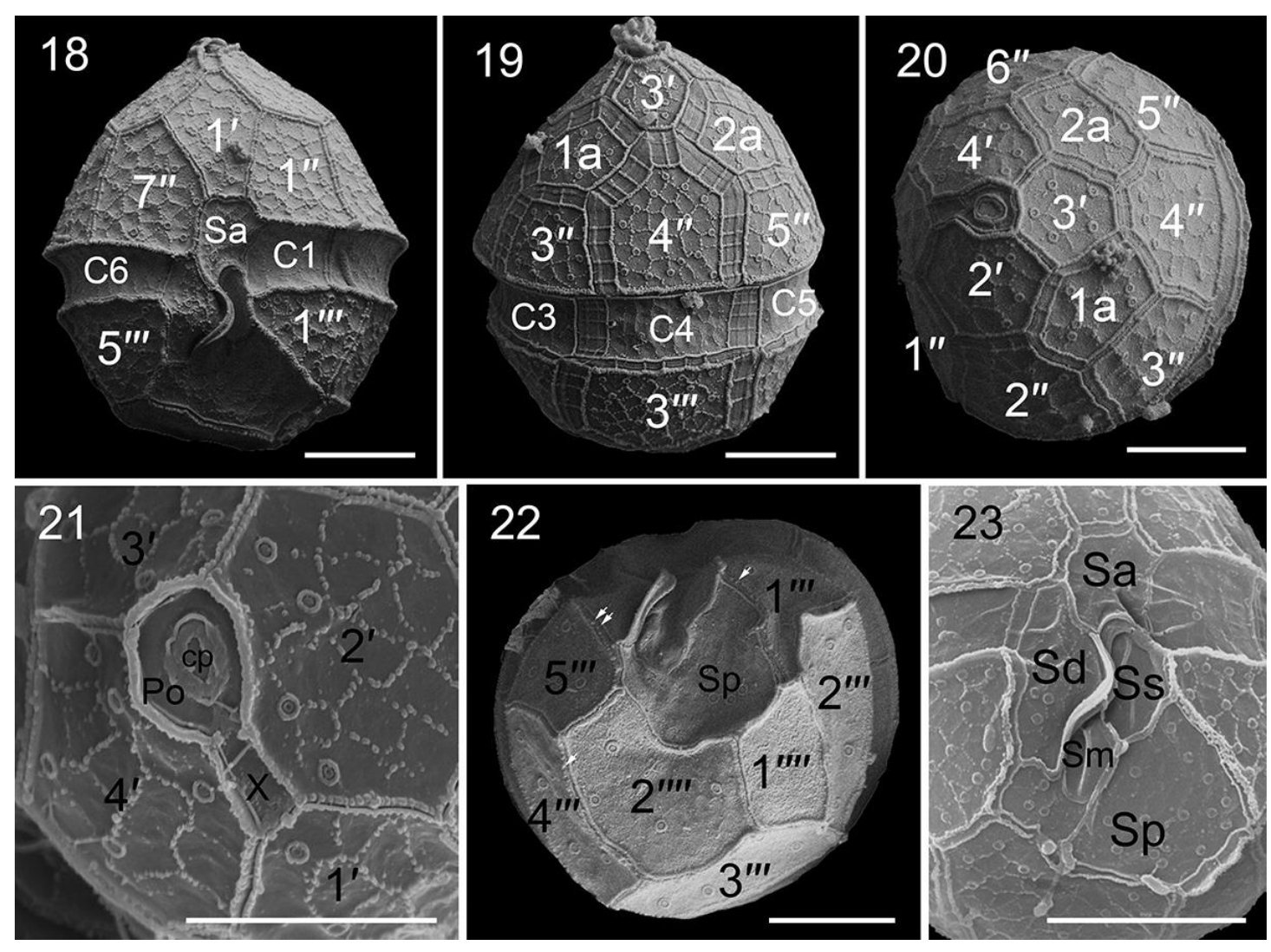

Fig. 24. Phylogeny of Johsia chumphonensis and Parvodinium parvulum inferred from concatenated SSU, ITS-5.8S and partial LSU rRNA (D1-D6) sequences using Bayesian inference (BI). New sequences are indicated in red. Branch lengths are drawn to scale, with the scale bar indicating the number of nucleotide substitutions per site. Numbers on branches are statistical support values to clusters on the right of them (left: Bayesian posterior probabilities (BPP); right: maximum likelihood (ML) bootstrap support (BS) values. Bootstrap support values $>50 \%$ and Bayesian posterior probabilities above 0.9 are shown. Asterisk indicates maximal support $(\mathrm{ML} \mathrm{BS}=100 \%$ and $\mathrm{BPP}=1.00)$. 


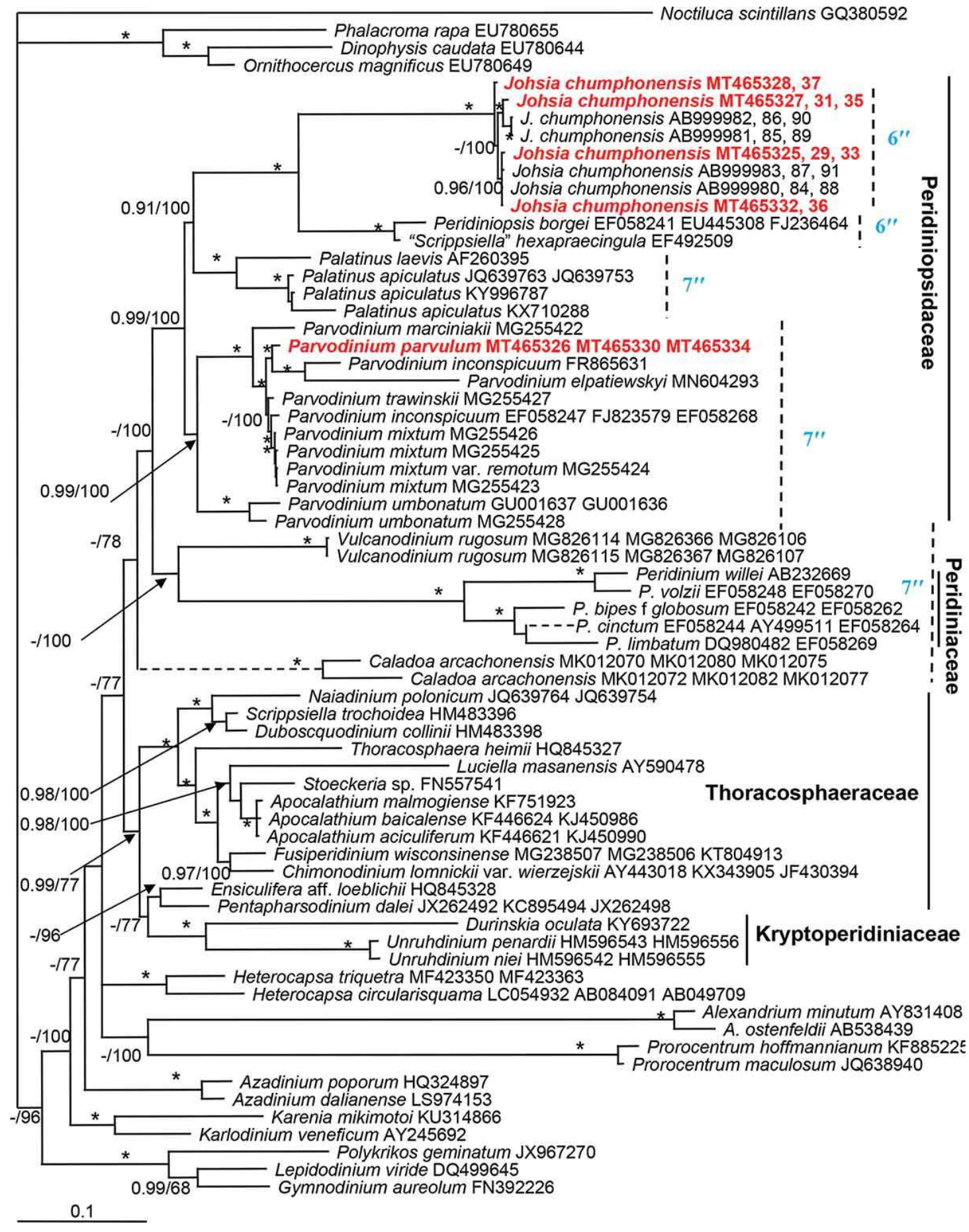

Figs S1-S4. Light and scanning electron micrographs of vegetative cells and cysts of Johsia chumphonensis strain TIO606. Fig. S1. Numerous cysts and empty thecae in old culture. Fig. S2. An empty cyst. Fig. S3. Cysts and a potential gamete (arrow). Fig. S4. Epifluorescence image of a SYBR Green-stained cell 
showing a round nucleus $(\mathrm{N})$. Scale: Fig. $\mathrm{S} 1=50 \mu \mathrm{m}$; Figs $\mathrm{S} 2, \mathrm{~S} 4=5 \mu \mathrm{m}$; Fig. $\mathrm{S} 3=10 \mu \mathrm{m}$.
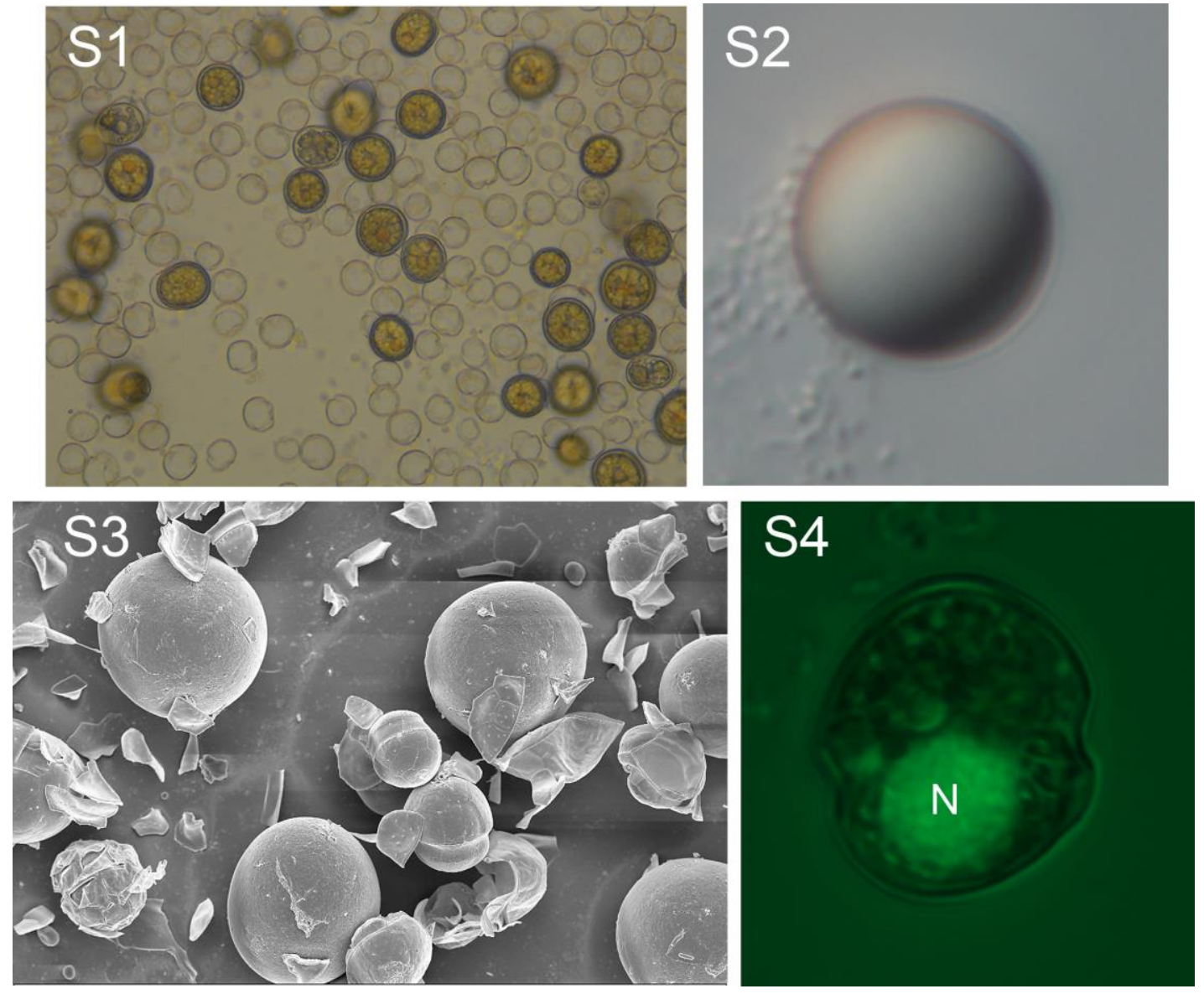

Figs S5-S8. Schematic drawings of thecal plate patterns of Johsia chumphonensis.

Fig. S5. Ventral view. Fig. S6. Dorsal view. Fig. S7. Apical view. Fig. S8. Antapical view. 

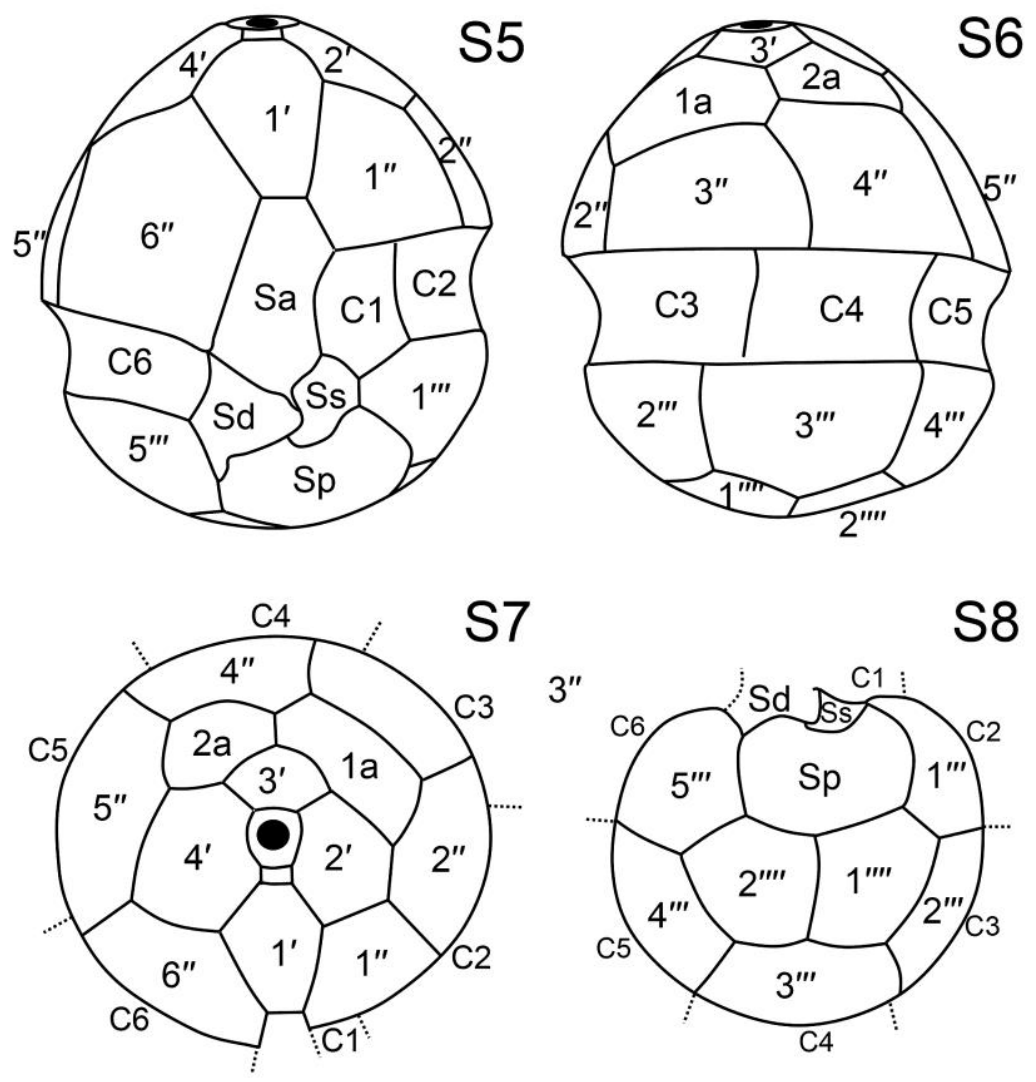

Fig. S9. Schematic drawing of Peridinium parvulum (redrawn fromWołoszyńska 1930). 


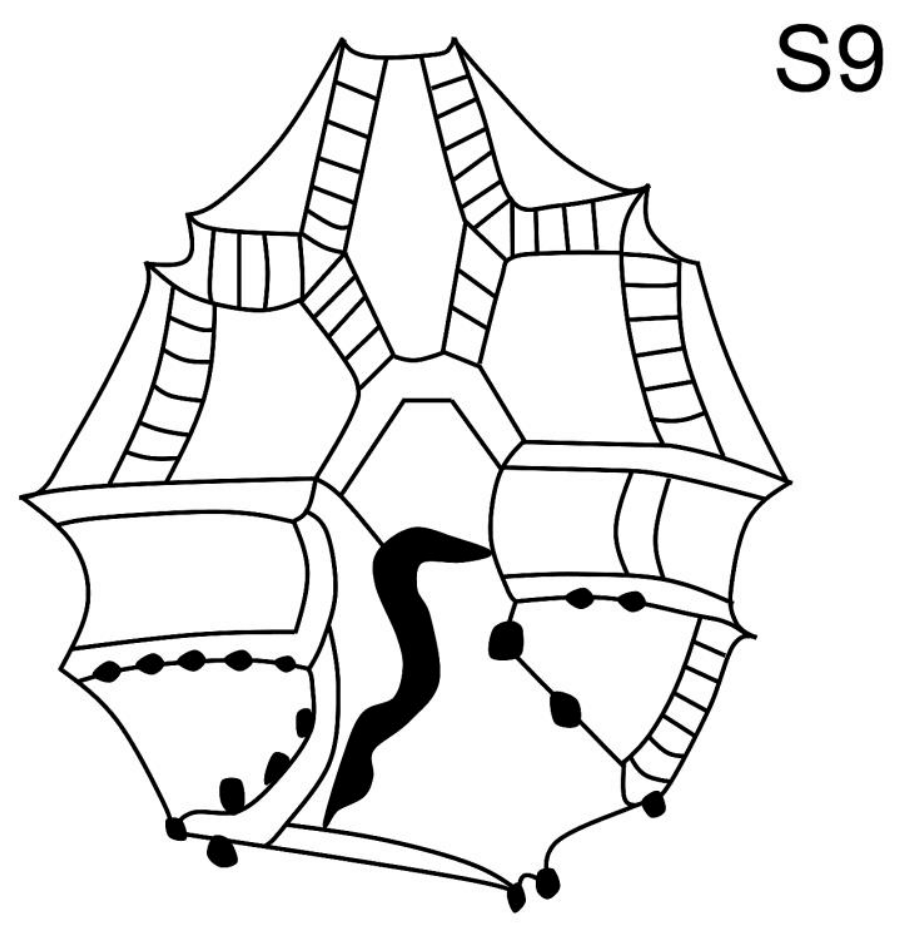

Figs S10-S15. Light micrographs of cells of Parvodinium parvulum strain TIO879.

Fig. S10. Ventral view showing a rounded epitheca and hypotheca with a prominent eyespot (arrow). Fig. S11. Dorsal view showing radially arranged chloroplasts (C). Fig. S12. Epifluorescence image of a cell in ventral view showing radial arranged chloroplasts. Fig. S13. Epifluorescence image of a SYBR Green-stained cell showing an elongated nucleus (N). Fig. S14. An ellipsoid cocooid cell. Fig. S15. A spherical coccoid cell showing granules and chloroplasts inside. Scale bars $=5 \mu \mathrm{m}$. 


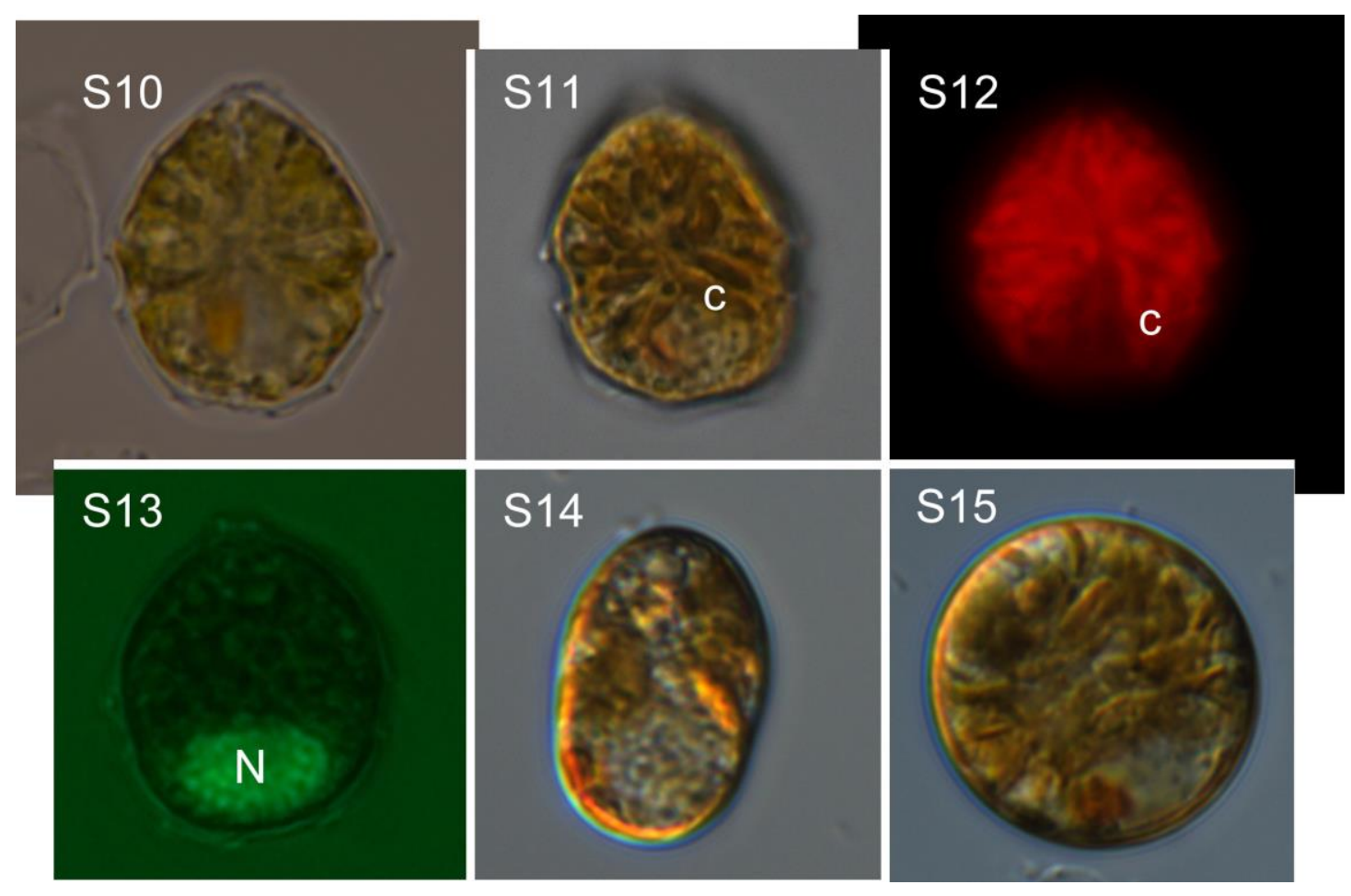

Figs S16, S17. Transmission electron micrographs of vegetative cells of Parvodinium parvulum strain TIO879. Fig. S16. Longitudinal sections through the vegetative cell showing a large nucleus $(\mathrm{N})$, radial chloroplasts $(\mathrm{C})$ and starch grains $(\mathrm{S})$.

Fig. S17. The eyespot (e) located within a chloroplast (c) comprising four rows of globular lipids. Scale: Fig. S16 = 5 $\mu \mathrm{m}$; Fig. S17 $=1 \mu \mathrm{m}$.
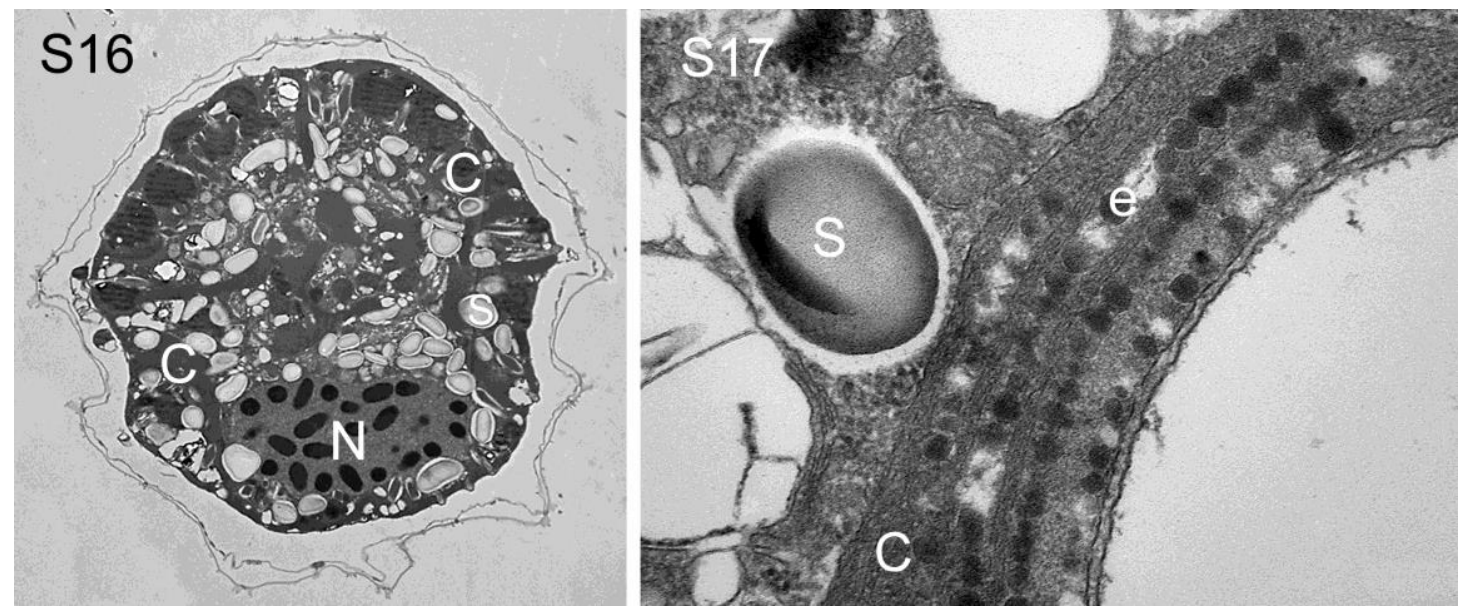
Figs S18, S19. Schematic drawing of Peridinium javanicum (redrawn from Bernard, 1908) and Peridinium caudatum var. morsum (redrawn from Playfair, 1919).
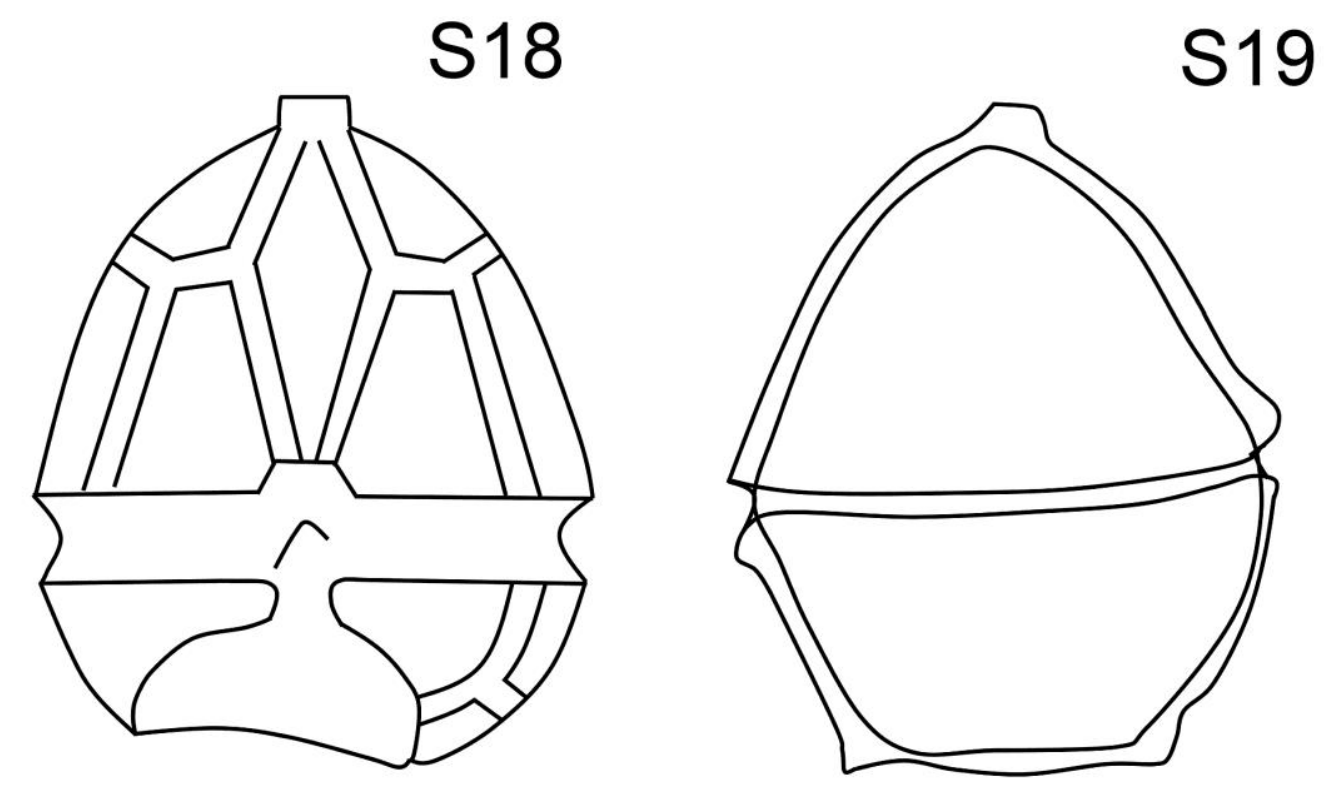